\title{
QUARTERLY ANALYSIS: \\ The Progress of Monetary, Banking and Payment System Second Quarter - 2010
}

\author{
Author Team of Quarterly Report, Bank Indonesia
}

The Indonesian economy in second quarter of 2010 demonstrated a continued strengthening. This optimism was supported by investment and export performance that grows higher, in line with the global economic recovery. Economic conditions continued to show an atmosphere that supports the optimistic better economic outlook than previously thought. The Indonesian economy in 2010 was estimated to grow towards the upper limit of the range of $5.5 \%-6.0 \%$ and reached $6.0 \%-6.5 \%$ in 2011 . In terms of prices, inflationary pressure throughout the second quarter of 2010 showed an increase caused by the volatile foods, such as various spices and rice. Meanwhile, the administered prices group and minimal core inflation contributed to the price development during the second quarter of 2010. Thus, overall the year, CPI inflation in 2010 will still be in the range of the inflation target of $5 \% \pm 1 \%$.

The global economic recovery still continues, although shadowed by the pressure on global financial markets and concerns about sustainability of Europe's economic recovery. The rate of global economic recovery in the second quarter of 2010 was expected to moderate compared with the first quarter of 2010. Nevertheless, these developments that remain positive have raised optimism on global recovery process. The condition was supported by the improving conditions in developed countries, especially the United States (U.S.) and Japan, as well as a number of countries in Asia.

In Asia, economic growth showed an increase, in except China which slowed slightly, related to policies pursued by the Chinese government to overcome the symptoms of overheating. European crisis has triggered pressure on global financial markets during the second quarter of 2010, and was reflected by the significant drop in global stock markets and the soaring Credit Default Swap (CDS) and the yield spread of PIIGS (Portugal, Italy, Ireland, Greece, and Spain). In Asia, the flight to quality was indicated from the position of net selling by foreign investors in the stock market, the weakening regional currencies, as well as the rising of sovereign CDS. So far the impact crisis in Europe has only affected the global financial markets and yet to significantly influence the overall global economic recovery. Various measures have been taken 
by countries which experienced the crisis in Europe such as the austerity program, the help of European Union (EU) and the International Monetary Fund (IMF) and so far they are capable of dampening the global financial market turmoil that occurred during the second quarter of 2010

Domestic economic performance the second quarter of 2010 was expected to be better than previous projections. In the second quarter of 2010, the domestic economy was expected to grow $6.0 \%$, higher than the previous projection of $5.7 \%$. This optimism was supported by the investment performance that rises higher. Investment growth was expected to reach $10 \%$ (yoy) in the second quarter of 2010, as a response from domestic and external demand was getting stronger. Better investment climate was also supported by Indonesia's sovereign credit rating which increased along with the improvement of economic fundamentals.

By sector, economic performance in 2010 was mainly supported by trade, hotels, and restaurants and transport and communications sector. Acceleration for higher domestic economy needs more support, especially related to the acceleration of the implementation of infrastructure programs.

Improved economic growth, also reflected in regional economic growth that continued to grow strong. The performance of the local economy was sustained by the economy activities, especially in Jakarta, West Java, East Java and Sulawesi, Maluku and Papua. Performance of the improved regional economic development has been driven mainly by improved performance in consumption, investment and exports. Growth in household consumption remained strong in the area, indicated by the increasing growth of consumer credit, retail sales growth remained high, and stable exchange rate of farmers in various regions. In addition, the regional elections, which many of them took place in the second quarter of 2010, also played a role in increasing local consumption. From the investment side, the increase occurred mainly in construction investment.

Investment activities in building showed an increase in Sumatera, Jakarta and Java, Bali and Nusa Tenggara. Construction investment activities in these areas, were mostly for the commercial and residential property sector. In terms of exports, a considerable growth remained in Kalimantan, Sulawesi, Maluku and Papua and Sumatra to Jakarta for mining commodities and products, as well as in Java, Bali and Nusa Tenggara for manufacturing product.

In terms of prices, inflationary pressure throughout the second quarter of 2010 showed an increase that came from the non-fundamental factor. The rising prices of spices and rice commodities along the second quarter of 2010 have put a significant pressure on CPI. The inflation of CPI in June 2010 was recorded at 0.97 ( $\mathrm{mtm})$, higher than previous months like in 
May, and $0.15 \%-0.14 \%$ in April 2010. With these developments, during the second quarter of 2010, CPI inflation stood at 1.41 (qtq) or reached $5.05 \%$ (yoy), increased significantly compared with the previous quarter which reached $0.99 \%$ (qtq) or $3.43 \%$ (yoy).

The high inflation of food commodities was due to the supply constraints triggered by the disruption of production and distribution due to heavy rainfall in some areas. Meanwhile, the price development of the administered prices group had relatively small impact on CPI inflation. In terms of fundamentals, core inflation pressures were still relatively low, which was sustained by the controlled expectations of inflation, the minimum external pressure and the adequate supply response toward the rising demand. Despite the increase of inflationary pressures in the second quarter of 2010, in general, the CPI inflation is expected to remain in the range of the inflation target of $5 \% \pm 1 \%$.

The conducive global economic conditions and the strong domestic economic fundamentals have supported Indonesia's balance of payments (neraca pembayaran Indonesia/ NPI) in second quarter of 2010 to remain solid. The current account recorded a surplus estimated, mainly due to the global economic recovery that continued and the rising trend of global commodity prices.

In terms of balance sheet capital and financial (transaksi modal dan financial/TMF) of the second quarter 2010, it is also expected to record a surplus. TMF surpluses were supported by the re-entry of foreign capital flows in line with the global financial market turmoil which has subsided and the repair of credit rating outlook for Indonesia. With these developments, the national reserves at the end of June 2010 reached 76.3 billion U.S. dollars, equivalent to 5.9 months of imports and foreign debt repayments by the Government.

Along with a solid performance of balance of payments and the sustained low risks, exchange rate is in the strong trends. When compared with the first quarter of 2010, on average, the rupiah was appreciated by $1.58 \%$ (qtq), reaching Rp.9.110 per U.S. dollar. The strengthening of rupiah in the second quarter was followed by the volatility-which fell from $0.57 \%$ in the first quarter of 2010 to $0.47 \%$ in second quarter of 2010 .

At the end of second quarter of 2010 rupiah closed at Rp9.060 per U.S. dollar, or gained $0.33 \%$ (ptp) compared with the first quarter of 2010. Package policies issued by Bank Indonesia on June 15, 2010 was generally positively responded by market participants both domestically and internationally so that the pressure on the rupiah exchange rate were relieved, and further strengthened the monetary management and the deepening of financial markets.

The overall financial market performance in the second quarter of $2010 \mathrm{improved}$, despite temporarily depressed in May 2010. SUN market and capital markets condition gradually 
improved, after a depressed negative sentiment caused by the Europe's debt crisis in May 2010. The improvement in capital markets and securities in the second quarter of 2010 was supported by the re-entry of foreign investors and the relieved bubble pressure on the stock market.

On the interbank money market, the liquidity conditions during the second quarter of 2010 were sufficiently good. The extension of corridor of PUAB O/N per June 17, 2010 had an impact on the decline in PUAB O/N rates. Parallel with the improving global conditions and domestic fundamentals, monetary policy transmission continued to improve. This was reflected in the decline of deposit and credit rates, and credit growth which increased was estimated to reach $18.6 \%$ by June 2010 .

From the micro-banking side, national banking conditions remained stable. This was reflected from the maintained capital adequacy ratio (CAR) as of May 2010 amounted to $17.8 \%$. Meanwhile, the ratio of gross non-performing loans (NPLs) remained at $3.6 \%$ with a net ratio of $1 \%$. In addition, bank liquidity, including liquidity in the interbank money market sustainably improved and third-party funds (TPF) remained increasing.

It is considered that the $\mathrm{BI}$ Rate at $6.5 \%$ rate was still consistent with the inflation target for 2010 at $5 \% \pm 1 \%$ and the current direction of monetary policy were also considered conducive for the economic recovery amid the high global risk resulted from the debt crisis in a number of European countries. The Bank Indonesia Board of Governors Meeting on July 5, 2010 decided to maintain the $\mathrm{BI}$ Rate at $6.5 \%$, with the corridor of PUAB O/N rate as the operational target for monetary policy \pm 100 bps. 